\title{
Glucose and protein metabolism during late pregnancy in triplet-bearing ewes given fresh forages ad lib.
}

\author{
1. Voluntary intake and birth weight \\ BY T. N. BARRY* AND T. R. MANLEY \\ Invermay Agricultural Research Centre, Private Bay, Mosgiel, New Zealand
}

(Received 20 November 1984 - Accepted 3 May 1985)

\begin{abstract}
1. Ewes of the Booroola $\times$ Romney genotype carrying triplet lambs were given fresh forages ad lib. in late pregnancy. In Expt 1, groups of three ewes were given kale (Brassica oleracea), perennial ryegrass (Lolium perenne) or perennial ryegrass $(0.75)$-barley $(0.25)$. In Expt 2 , groups of two or three ewes were given fresh perennial ryegrass and infused into the abomasum with iso-energetic quantities of casein and glucose in a $2 \times 2$ factorial arrangement. Post-lambing ewe live weights were $40-50 \mathrm{~kg}$. Glucose irreversible loss (GIL) was determined from dilution of $\mathrm{D}-\left[\mathrm{U}-\mathrm{-}^{14} \mathrm{C}\right] \mathrm{glucose}$.

2. For ewes given kale, perennial ryegrass and perennial ryegrass-barley in Expt 1, mean metabolizable energy (ME) intakes were $0.50,0.82$ and $0.83 \mathrm{MJ} / \mathrm{kg}$ live weight ${ }^{0.75}$ per d, GIL was 112,142 and $157 \mathrm{~g} / \mathrm{d}$, and mean birth weight $2 \cdot 22,3.05$ and $2.95 \mathrm{~kg} / \mathrm{lamb}$.

3. In Expt 2, infusion of glucose, casein, and glucose + casein depressed herbage ME intake respectively by $1 \cdot 6$, 0.9 and 0.3 times the amount of ME infused. GIL (185-325 g/d) was increased by 800 and $350 \mathrm{~g}$ respectively for each $\mathrm{kg}$ of glucose or casein infused. Casein infusion increased calculated amino acid absorption from 0.18 to 0.36 of ME, increased wool growth and increased calculated maternal $\mathrm{N}$ balance. Birth weight was unaffected by nutritional treatment and averaged $3 \cdot 29 \mathrm{~kg} / \mathrm{lamb}$.

4. When values from both experiments were combined, birth weight was related to GIL by a hyperbolic relation, with maximum predicted birth weight being $4 \cdot 1 \mathrm{~kg} / \mathrm{lamb}$. It was postulated that this value was never attained in practice, due to uterine expansion being restricted by the low maternal body size. Marked decreases in birth weight occurred when GIL decreased below $173 \mathrm{~g} / \mathrm{d}$.

5. It was calculated that ewes in all treatment groups were in negative energy balance, and that glucose supplied by the kale and unsupplemented ryegrass diets were respectively below and equal to calculated conceptus uptakes of glucose necessary to maintain growth of triplet fetuses. It was further calculated that amino acid requirements of triplet-bearing ewes in late pregnancy were likely to exceed substantially net absorption from digestion of fresh forage diets, and that maternal tissues go into negative $\mathrm{N}$ balance to ensure fetal growth, thus explaining the lack of response to abomasal casein infusion.
\end{abstract}

Newton-Turner (1982) reported the occurrence of a high fecundity strain of Merino sheep in Australia, which have been named Booroola Merino after the property where they originated. Booroola Merino rams were imported into New Zealand (NZ) in 1973, and have been extensively crossed with Romney sheep to produce a crossbred ewe with a high ovulation rate and lambing percentage. Progress in producing highly fecund ewes has been rapid since the identification of very high ovulation rates $(>3)$ as inherited by a single gene (Davis et al. 1982; Piper \& Bindon, 1982; Davis \& Hinch, 1984). Highly fecund Booroola $\times$ Romney ewes are characterized by a low body-weight $(40-45 \mathrm{~kg})$, with approximately $40 \%$ of the ewes giving birth to triplets. Birth weight of triplet lambs born to Booroola $\times$ Romney ewes managed under pastoral conditions in NZ is low $(2.9 \mathrm{~kg})$ and neonatal mortality high. The objectives of the research reported here were to gain knowledge of nutrient utilization during late pregnancy of triplet-bearing Booroola $\times$ Romney ewes given fresh forages $a d l i b$. with a view to devising nutritional treatments that could increase birth weight and, hence, lamb survival under field conditions (Dalton et al. 1980).

The developing uterus in the sheep is specific in taking up mainly glucose and amino acids

\footnotetext{
* Present address: Department of Animal Science, Massey University, Palmerston North, New Zealand.
} 
as sources of energy (Hopkins, 1975). The experiments reported were designed to study the effects of changing maternal glucose production and amino acid absorption, either indirectly through changing metabolizable energy (ME) intake, or directly by abomasal infusion of glucose and protein, in ewes given fresh forage of high ME and nitrogen contents. It was concluded that fetal growth in these ewes was limited by the low maternal body size, and that the ewes went into negative maternal energy and $\mathrm{N}$ balance in late pregnancy in order to ensure fetal growth.

\section{MATERIALS AND METHODS}

\section{Experimental design}

Two experiments were conducted with Booroola $\times$ Romney ewes given fresh forages ad lib. Throughout the experiments, the ewes were fed individually in pens.

\section{Animals and diets}

Booroola $\times$ Romney ewes conceiving during one half of the oestrus cycle only were X-rayed at $85 \mathrm{~d}$ of pregnancy, and those carrying triplets identified. The ewes were then brought indoors and given fresh forages ad lib. during late pregnancy. Fresh pasture, containing perennial ryegrass (Lolium perenne)-white clover (Trifolium repens) $(0 \cdot 9: 0 \cdot 1, \mathrm{w} / \mathrm{w})$, was given in most instances, hence referred to as perennial ryegrass because of the dominance of this component. The forages were grown and fed over the late winter-early spring period. All diets were chopped into $40-80 \mathrm{~mm}$ lengths before feeding and fluorescent lighting was continuously provided. Duplicate samples of feed offered and residues were taken daily, pooled over a $10 \mathrm{~d}$ period in Expt 1 and weekly in Expt 2 at $-20^{\circ}$, and then freeze-dried and ground. Voluntary intake was calculated over these same periods. Lambs were dried after parturition and weighed. Ewes were weighed the day after parturition, and then turned out to graze with their lambs.

All ewes were given a $1 \mathrm{ml}$ intramuscular injection of iodized poppy seed oil supplying $475 \mathrm{mg}$ iodine, in mid-pregnancy (Lipiodol; May \& Baker, NZ), to protect against goitrogens in the kale (Brassica oleracea) diet and the low level of I in ryegrass-based pastures grown at this Centre (100-200 $\mu \mathrm{g} / \mathrm{kg}$ dry matter (DM)). The ewes were also given orally $5 \mathrm{mg}$ selenium as sodium selenate the day they were brought indoors.

\section{Expt 1}

Groups of three ewes were given either diets of fresh forage kale, fresh perennial ryegrass or fresh ryegrass-rolled barley $(0 \cdot 75: 0 \cdot 25, \mathrm{w} / \mathrm{w}, \mathrm{DM}$ basis). The kale-fed ewes were selected from a larger group that had grazed this crop since mid-pregnancy, whilst the other ewes were selected from a larger group that had grazed ryegrass. The ewes were brought indoors 5 weeks before parturition was expected and given the fresh diets in two equal feeds at 09.00 and 16.00 hours. Some 4 weeks before parturition, the ewes were introduced to feeding at 3-h intervals from overhead belt feeders, and indwelling catheters inserted into both jugular veins. Glucose irreversible loss (GIL) was determined once for each ewe from a primed continuous $7 \mathrm{~h}$ infusion of $\mathrm{D}-\left[\mathrm{U}-{ }^{14} \mathrm{C}\right]$ glucose during the period $18-21 \mathrm{~d}$ before parturition, using the procedures described by Barry et al. (1985). ME intake was calculated for the period $14-23 \mathrm{~d}$ before parturition.

\section{Expt 2}

Ten ewes fitted with abomasal catheters were given fresh vegetative primary growth perennial ryegrass for 6 weeks before parturition. All received a continuous abomasal infusion supplying 2 litres fluid/d. Three ewes received glucose dissolved in the infusate 
$(175 \mathrm{~g} / \mathrm{d} ; 2.50 \mathrm{MJ} \mathrm{ME})$, two received sodium caseinate (115 $\mathrm{g}$ as casein/d; $2.20 \mathrm{MJ} \mathrm{ME})$, a further two received a mixture of $146 \mathrm{~g}$ glucose $(2.29 \mathrm{MJ} \mathrm{ME})$ and $119 \mathrm{~g}$ casein (2.28 MJ $\mathrm{ME}) / \mathrm{d}$, whilst a fourth group of three ewes acted as control. Organic matter (OM) comprised respectively 1.00 and 0.98 of the glucose and sodium caseinate. Control ewes received an infusion of disodium hydrogen orthophosphate and sodium sulphate, which supplied the same amounts of sodium, phosphorus and sulphur as supplied by the infusions of sodium caseinate. The glucose and casein treatments were designed to be iso-energetic for ME in so far as was practicable, assuming a metabolizability of infused energy of 1.0 for glucose and 0.8 for casein (Blaxter, 1962), and to double GIL and amino acid absorption based on values obtained in Expt 1 for ewes given the perennial ryegrass diet.

Mid-side wool patches of $122.5 \mathrm{~mm} \times 122.5 \mathrm{~mm}$ were clipped on the left side of all animals at the start of the experiment, at parturition, and after a post-treatment grazing period of $45 \mathrm{~d}$. The ewes were maintained on hourly feeding during the period 5-2 weeks before parturition. Indwelling catheters were placed in both jugular veins of each ewe at the start of this perod, and GIL determined once for each ewe during the period 18-27 d before parturition using the methods described in Expt 1.

Following parturition, 10 i.u. oxytocin (Pitocin; Parke Davies, Sydney) was given to each ewe via a jugular catheter and all colostrum then removed from the udder, weighed, sampled for chemical analysis, and the remainder bottle-fed to the lambs.

\section{Laboratory methods}

Chemical composition and in vitro OM digestibility of feed offered and feed residues, and colostrum composition, were determined as described by Barry (1980). Plasma glucose concentraion and specific radioactivity (SRA) were determined as described by Barry et al. (1985).

\section{Calculation of results and statistical analyses}

ME intake was calculated assuming 16.3 MJ ME/ $\mathrm{kg}$ herbage digestible OM (DOM) consumed (Ulyatt et al. 1980). GIL was calculated as:

$$
\frac{\text { glucose infusion rate (disintegrations/min) }}{\text { plasma glucose plateau SRA (disintegrations/min per mg glucose) }} \text {. }
$$

In Expt 1, plateau SRA was determined in venous blood samples taken at $-1 \cdot 5,0.5$, 1.0 and $2.0 \mathrm{~h}$ following the commencement of a $3 \mathrm{~h}$ feeding cycle, with the first sample $(-1.5 \mathrm{~h})$ being taken after the infusion had been going for $4.0 \mathrm{~h}$. SRA in Expt 2 was calculated as the mean of three determinations on venous blood taken at 45 -min intervals during 5-7 $\mathrm{h}$ after the commencement of the infusion, the results of earlier samples having established that plateau SRA had been reached by this time.

Glucose concentration and GIL values in Expt 1 were initially analysed by a split-plot procedure, with nutritional treatments as main plots and sampling times as sub-plots. This showed no significant effects of time and no time $\times$ treatment interactions $(P>0.05)$, showing that plateau conditions had been attained, and all subsequent analyses were done using the means of the four sampling times.

Expt 2 values were analysed as a $2 \times 2$ factorial with unequal replication. Voluntary intake values in Expt 2 were also analysed using a split-plot procedure, with nutritional treatments as main plots and time (weeks) as sub-plots. Using combined values from both experiments, linear regressions were constructed of lamb birth weight $(Y) v$. the reciprocal of GIL $(1 / X)$ :

$$
Y=a+(b / X) \text {. }
$$

The plot of $Y v, X$ is therefore hyperbolic, with the intercept $a$ representing the theoretical assymptote or maximum value of $Y$ when $X$ is infinity. This equation gave a better fit to 
Table 1. Chemical composition $(\mathrm{g} / \mathrm{kg}$ dry matter $(D M))$ of the diets fed

\begin{tabular}{|c|c|c|c|c|}
\hline & \multicolumn{3}{|c|}{ Expt 1} & \multirow{2}{*}{$\begin{array}{c}\text { Expt } 2 \\
\begin{array}{c}\text { Perennial } \\
\text { ryegrass }\end{array}\end{array}$} \\
\hline & $\begin{array}{c}\text { Kale } \\
\text { (Brassica } \\
\text { oleracea) }\end{array}$ & $\begin{array}{c}\text { Perennial } \\
\text { ryegrass } \\
\text { (Lolium } \\
\text { perenne) }\end{array}$ & $\begin{array}{c}\text { Perennial } \\
\text { ryegrass- } \\
\text { barley }\end{array}$ & \\
\hline Organic matter $(\mathrm{OM})$ & 902 & 877 & 980 & 887 \\
\hline $\begin{array}{l}\text { OM digestibility } \\
(\mathrm{g} / \mathrm{kg} \mathrm{OM})^{*}\end{array}$ & 846 & 823 & 851 & 811 \\
\hline $\begin{array}{l}\text { Metabolizable energy (ME) } \\
(\mathrm{MJ} / \mathrm{kg} \mathrm{DM}) \dagger\end{array}$ & $12 \cdot 4$ & 11.8 & $13 \cdot 6$ & $11 \cdot 7$ \\
\hline Total nitrogen & $33 \cdot 8$ & $44 \cdot 7$ & $19 \cdot 3$ & $38 \cdot 6$ \\
\hline Total sulphur & $7 \cdot 2$ & $2 \cdot 6$ & $1 \cdot 2$ & $2 \cdot 0$ \\
\hline
\end{tabular}

* Measured in vitro.

$\uparrow$ Calculated assuming 16.3 MJ ME $/ \mathrm{kg}$ digestible OM (Ulyatt et al. 1980).

Table 2. Expt. 1. Ewe live weight $(W)$ and lamb birth weight, together with voluntary intakes of organic matter $(O M)$, metabolizable energy $(M E)$ and total nitrogen and indices of glucose metabolism in the ewes during late pregnancy

(Mean values with their standard errors for three animals per group)

\begin{tabular}{|c|c|c|c|c|}
\hline & $\begin{array}{c}\text { Kale } \\
\text { (Brassica } \\
\text { oleracea) }\end{array}$ & $\begin{array}{l}\text { Perennial } \\
\text { ryegrass } \\
\text { (Lolium } \\
\text { perenne) }\end{array}$ & $\begin{array}{c}\text { Perennial } \\
\text { ryegrass- } \\
\text { barley }\end{array}$ & SEM \\
\hline Ewe W (kg) & $40 \cdot 2$ & $41 \cdot 2$ & $41 \cdot 4$ & 3.59 \\
\hline Lamb birth wt (kg/lamb) & $2 \cdot 22$ & $3 \cdot 05$ & 2.95 & 0.230 \\
\hline \multicolumn{5}{|l|}{ Voluntary intake: } \\
\hline $\mathrm{OM}(\mathrm{g} / \mathrm{d})$ & 590 & 985 & 983 & $49 \cdot 7$ \\
\hline \multicolumn{5}{|l|}{ ME: } \\
\hline $\mathrm{MJ} / \mathrm{d}$ & $8 \cdot 0$ & $13 \cdot 3$ & $13 \cdot 4$ & 0.66 \\
\hline $\mathrm{MJ} / \mathrm{kg} \mathrm{W}^{0.75}$ per d & $0 \cdot 50$ & 0.82 & $0 \cdot 83$ & 0.046 \\
\hline Total N (g/d) & $23 \cdot 3$ & $50 \cdot 1$ & $42 \cdot 3$ & $2 \cdot 33$ \\
\hline \multicolumn{5}{|l|}{ Glucose metabolism: } \\
\hline $\begin{array}{l}\text { Plasma concen- } \\
\text { tration }(\mathrm{mg} / \mathrm{l})\end{array}$ & 499 & 575 & 650 & 37.2 \\
\hline \multicolumn{5}{|l|}{ Irreversible loss: } \\
\hline $\mathrm{mg} / \mathrm{min}$ & $78 \cdot 0$ & $98 \cdot 7$ & $109 \cdot 0$ & $4 \cdot 01$ \\
\hline $\mathrm{mg} / \mathrm{min}$ per $\mathrm{kg} \mathrm{W}^{0.75}$ & 4.93 & $6 \cdot 15$ & 6.86 & 0.726 \\
\hline $\mathrm{g} / \mathrm{d}$ & $112 \cdot 3$ & $142 \cdot 1$ & $157 \cdot 0$ & 5.77 \\
\hline proportion ME intake & $0 \cdot 152$ & $0 \cdot 113$ & 0.128 & $0 \cdot 0088$ \\
\hline
\end{tabular}

the values and more realistic assymptote values than double reciprocal plots used to calculate Michaelis-Menten kinetics.

\section{RESULTS}

Chemical composition of the diets

All forage diets used were of high in vitro $O M$ digestibility, and contained high concentrations of ME and total $\mathrm{N}$ (Table 1). The kale diet also contained high concentrations of total S 
Table 3. Expt. 2. Ewe live weight (W) and lamb birth weight, together with voluntary intake, indices of glucose metabolism, colostrum and wool production in the ewes during late pregnancy

(Mean values with their standard errors for three animals in the control and glucose groups, and two animals in the casein and glucose + casein groups)

\begin{tabular}{|c|c|c|c|c|c|c|}
\hline & \multirow[b]{2}{*}{ Control } & \multirow[b]{2}{*}{ Glucose } & \multirow[b]{2}{*}{ Casein } & \multirow{2}{*}{$\begin{array}{c}\text { Glucose }+ \\
\text { casein }\end{array}$} & \multicolumn{2}{|c|}{ SEM } \\
\hline & & & & & $n 3$ & $n 2$ \\
\hline W $(\mathrm{kg})$ & $48 \cdot 1$ & $45 \cdot 3$ & $51 \cdot 0$ & $51 \cdot 6$ & $2 \cdot 87$ & $3 \cdot 51$ \\
\hline Birth wt (kg/lamb) & $3 \cdot 26$ & $3 \cdot 12$ & $3 \cdot 57$ & $3 \cdot 28$ & $0 \cdot 201$ & $0 \cdot 246$ \\
\hline \multicolumn{7}{|l|}{ Voluntary intake: } \\
\hline Herbage organic matter $(\mathrm{g} / \mathrm{d})$ & 929 & 631 & 779 & 808 & $71 \cdot 3$ & $87 \cdot 3$ \\
\hline \multicolumn{7}{|l|}{ Metabolizable energy (ME): } \\
\hline Herbage $(\mathrm{MJ} / \mathrm{d})$ & $12 \cdot 3$ & 8.4 & $10 \cdot 4$ & $10 \cdot 8$ & 0.96 & $1 \cdot 17$ \\
\hline Infusate $(\mathrm{MJ} / \mathrm{d})$ & 0 & $2 \cdot 5$ & $2 \cdot 2$ & $4 \cdot 5$ & & \\
\hline Total: $\mathrm{MJ} / \mathrm{d}$ & $12 \cdot 3$ & $10 \cdot 9$ & $12 \cdot 6$ & $15 \cdot 3$ & 0.97 & $1 \cdot 18$ \\
\hline $\mathrm{MJ} / \mathrm{kg} \mathrm{W}^{0.35}$ perd & 0.68 & 0.63 & 0.66 & 0.80 & 0.091 & 0.112 \\
\hline Herbage total nitrogen $(\mathrm{g} / \mathrm{d})$ & 40.0 & $27 \cdot 2$ & $33 \cdot 6$ & 34.9 & $3 \cdot 32$ & $4 \cdot 06$ \\
\hline \multicolumn{7}{|l|}{ Glucose metabolism: } \\
\hline Plasma concentration (mg/l) & 520 & 711 & 590 & 747 & $30 \cdot 2$ & 27.0 \\
\hline \multicolumn{7}{|l|}{ Irreversible loss: } \\
\hline $\mathrm{mg} / \mathrm{min}$ & $128 \cdot 3$ & $170 \cdot 8$ & $142 \cdot 6$ & $225 \cdot 9$ & $9 \cdot 14$ & $11 \cdot 19$ \\
\hline $\mathrm{mg} / \mathrm{kg} \mathrm{W}^{0.75}$ per $\min$ & 7.08 & $9 \cdot 82$ & $7 \cdot 53$ & 11.79 & 0.717 & 0.878 \\
\hline $\mathrm{g} / \mathrm{d}$, unadjusted & $184 \cdot 7$ & 246.0 & $205 \cdot 3$ & $325 \cdot 2$ & $13 \cdot 16$ & $16 \cdot 11$ \\
\hline $\mathrm{g} / \mathrm{d}$, adjusted $^{*}$ & 155.6 & $282 \cdot 6$ & $200 \cdot 0$ & $319 \cdot 3$ & 7.96 & $9 \cdot 74$ \\
\hline proportion ME intake & $0 \cdot 232$ & $0 \cdot 358$ & $0 \cdot 248$ & $0 \cdot 327$ & 0.0110 & 0.0135 \\
\hline \multicolumn{7}{|l|}{ Colostrum production: } \\
\hline Total $(\mathrm{g} / \mathrm{d})$ & $308 \cdot 7$ & $1017 \cdot 0$ & $809 \cdot 5$ & $764 \cdot 5$ & $204 \cdot 19$ & $250 \cdot 08$ \\
\hline Fat $(\mathrm{g} / \mathrm{d})$ & $48 \cdot 2$ & $147 \cdot 2$ & $142 \cdot 7$ & $124 \cdot 8$ & $35 \cdot 00$ & $42 \cdot 86$ \\
\hline Protein (g/d) & $61 \cdot 5$ & $173 \cdot 5$ & $176 \cdot 2$ & $136 \cdot 5$ & $47 \cdot 05$ & 57.62 \\
\hline Lactose (g/d) & $8 \cdot 3$ & $28 \cdot 2$ & $21 \cdot 4$ & $21 \cdot 7$ & $6 \cdot 14$ & $7 \cdot 53$ \\
\hline \multicolumn{7}{|l|}{ Wool production: } \\
\hline $\begin{array}{l}\text { Treatment period } \\
\left(\mathrm{mg} / 10^{4} \mathrm{~mm}^{2} \text { per } \mathrm{d}\right)\end{array}$ & $18 \cdot 8$ & $20 \cdot 0$ & $42 \cdot 7$ & $38 \cdot 6$ & $5 \cdot 63$ & $6 \cdot 90$ \\
\hline $\begin{array}{l}\text { Post-treatment period } \\
\left(\mathrm{mg} / 10^{4} \mathrm{~mm}^{2} \text { per } \mathrm{d}\right)\end{array}$ & $45 \cdot 0$ & $50 \cdot 7$ & $66 \cdot 1$ & $64 \cdot 0$ & $10 \cdot 85$ & $13 \cdot 29$ \\
\hline
\end{tabular}

* After adjustment to equal herbage ME intake of $10 \cdot 49 \mathrm{MJ} / \mathrm{d}$ by analysis of co-variance.

and, based on our previous experience (Barry et al. 1984), would contain in the order of $11 \mathrm{~g} / \mathrm{kg} \mathrm{DM}$ of the free amino acid S-methyl-L-cysteine sulphoxide (SMCO).

\section{Expt 1}

Voluntary intakes of $\mathrm{OM}, \mathrm{ME}$ and total $\mathrm{N}$ (Table 2) were considerably lower for ewes given kale than for ewes given the other two diets $(P<0.01)$. Consequently, lamb birth weight was less for ewes given kale $(P<0.05)$ than the mean combined value for ewes given the other two diets. Although wool growth was not measured directly, it was assumed to be zero for ewes given kale, as all three ewes on this diet showed wool shedding. Relative to ewes given perennial ryegrass, plasma glucose concentration and GIL tended to be depressed by kale feeding and increased by barley supplementation (Table 2), with the difference between kale and ryegrass-barley attaining significance $(P<0.05)$ for plasma glucose concentration and GIL ( $\mathrm{mg} / \mathrm{min}$ ). GIL as a proportion of ME intake (MEI) was greater for sheep given kale than perennial ryegrass $(P<0.05)$, and intermediate for sheep given ryegrass-barley. 


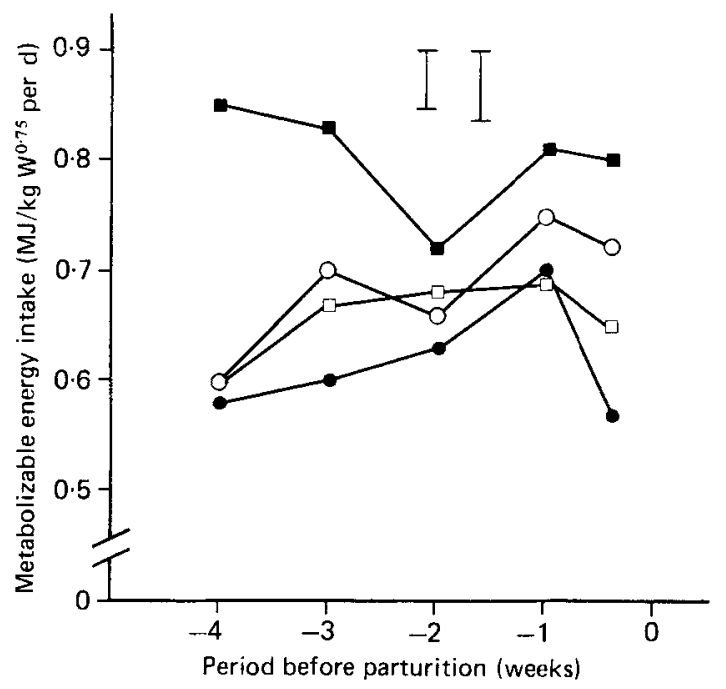

Fig. 1. Expt 2. Metabolizable energy intakes (herbage + infusate) during the last 4 weeks before parturition. (O), Control ewes; ( $)$, glucose infusion; ( $\square$ ), casein infusion; ( $\square$ ), infusion of glucose + casein. Points are mean values with their standard errors represented by vertical bars: the smaller value applies to comparisons between weeks within a nutritional treatment; the larger value applies to comparisons between nutritional treatments at any 1 week. Standard errors were calculated from error mean squares in the split-plot analysis of variance, using nutritional treatments as main plots and time (weeks) as sub-plots. W, live weight.

GIL $(\mathrm{mg} / \mathrm{min}$ ) was related to glucose concentration $(\mathrm{GC} ; \mathrm{mg} / \mathrm{l})$ by the equation:

$$
\mathrm{GIL}=7 \cdot 11(\mathrm{sE} 21.502)+0.153(\text { SE 0.0370) GC }(n 9, r 0.860, P<0.001) \text {. }
$$

GIL per unit metabolic body size (GILM; $\mathrm{mg} / \mathrm{min}$ per $\mathrm{kg}$ live weight $(\mathrm{W})^{0.75}$ ) and glucose concentration $(\mathrm{GC} ; \mathrm{mg} / \mathrm{l})$ were related to herbage $\mathrm{MEI}\left(\mathrm{MJ} / \mathrm{kg} \mathrm{W}^{0.75} \mathrm{per} \mathrm{d}\right)$ by the equations:

$$
\begin{aligned}
& \mathrm{GILM}=1 \cdot 71(\mathrm{SE} 1 \cdot 413)+5.88(\mathrm{SE} 1 \cdot 888) \mathrm{MEI}(n 9, r 0 \cdot 788, P<0 \cdot 05) . \\
& \mathrm{GC}=305.8(\mathrm{SE} 90 \cdot 76)+369 \cdot 3(\mathrm{SE} 121 \cdot 26) \mathrm{MEI}(n 9, r 0.779, P<0.05) .
\end{aligned}
$$

\section{Expt 2}

For values averaged over the last 4 weeks before parturition (Table 3), glucose infusion in the absence of casein depressed herbage MEI by 1.6 times the ME infused as glucose. In the absence of glucose, casein infusion depressed herbage MEI by an amount equivalent $(0.9)$ to the casein ME infused. Conversely, the combined glucose + casein infusion depressed herbage MEI by an amount equivalent to one third of the ME infused, with the result that total MEI (herbage + infusate) was increased by this treatment. The glucose $x$ casein interaction was significant $(P<0.01)$ for herbage and total MEI and also for herbage total $\mathrm{N}$ intake.

Total MEI was high and tended to decline over the last 4 weeks before parturition in the group infused with glucose + casein (Fig. 1). In contrast, MEI in the other three groups tended to rise over this period, but the infusion $\times$ time interaction was not significant $(P>0.05)$. MEI in all groups decreased during the last $3 \mathrm{~d}$ before parturition. As the amount of ME infused was maintained constant for each animal, these changes with time were due entirely to changes in herbage intake. 
Glucose infusion increased both plasma glucose concentration $(P<0.01)$ and GIL $(P<0.01$; Table 3$)$. Casein infusion increased both variates by smaller amounts, with the increase for GIL $(\mathrm{mg} / \mathrm{min})$ attaining significance $(P<0.05)$. GIL $(\mathrm{mg} / \mathrm{min})$ was related to $\mathrm{GC}(\mathrm{mg} / \mathrm{l})$ by the equation:

$$
\mathrm{GIL}=-30.52(\mathrm{SE} 48.236)+0.305(\mathrm{SE} 0.0748) \mathrm{GC}(n 10, r 0.821, P<0.01) .
$$

Changes in GILM (mg/min per $\left.\mathrm{kg} \mathrm{W}^{0.75}\right)$ were related to changes in herbage MEI $(\mathrm{MJ} / \mathrm{kg}$ $\mathrm{W}^{0.75}$ per d) by the following equation, derived from within-treatment variation only:

$$
\text { GILM }=-7.48 \text { (SE 1.420) +13.09 (SE 2.467) MEI }(n 10, r 0.921, P<0.01) \text {. }
$$

When GIL was corrected for differences in herbage MEI by analysis of co-variance (Table 3 ), glucose infusion increased GIL by amounts equivalent to 0.79 and 0.82 of the glucose infused in the absence and presence of casein respectively $(P<0.001)$. Casein infusion increased GIL by 390 and $310 \mathrm{~g} / \mathrm{kg}$ of the casein infused in the absence and presence of glucose infusion $(P<0.01)$. GIL as a proportion of MEI was markedly increased by glucose infusion $(P<0.001)$ but unaffected by casein infusion.

Individual lamb birth weight (Table 3) averaged $3.29 \mathrm{~kg}$ and was not affected by nutritional treatment $(P>0.05)$. There was a tendency for the production of total and individual components of colostrum to be increased by all three nutritional treatments, with the mean for the three treatment groups $(n 7)$ being greater $(P<0 \cdot 1)$ than that of the control group $(n 3)$. Wool growth rate in the $36 \mathrm{~d}$ treatment period was unaffected by glucose infusion, but was increased by casein infusion $(P<0.05)$, with the effect carrying over into the post-treatment period $(45 \mathrm{~d})$.

\section{DISCUSSION}

\section{Voluntary intake}

Amino acid absorption from the small intestine of ryegrass-fed animals can be calculated by inserting total $\mathrm{N}$ intake determined in the present study into the prediction equations of MacRae \& Ulyatt (1974), derived with wethers. The composition of the ryegrass used in the present study was similar to that used by MacRae \& Ulyatt (1974), and such derived values representing net amino acid absorption from the herbage component of the diet only for control sheep and sheep infused with glucose, casein and glucose + casein in Expt 2 were 93, 66, 79 and $82 \mathrm{~g} / \mathrm{d}$. Faichney (1984) reported duodenal $\mathrm{N}$ flows for twin-bearing ewes $20 \%$ greater than for non-pregnant ewes, and it is possible that the previously mentioned calculated values are underestimates. Nevertheless, they indicate that the amount of protein infused into the abomasum $(115 \mathrm{~g} / \mathrm{d})$ approximately doubled net amino acid absorption from the small intestine, and increased calculated net amino acid absorption as a proportion of $\mathrm{ME}$ from 0.18 and 0.14 for control and glucose-infused sheep to 0.36 and 0.31 for sheep infused with casein and glucose + casein.

As found by Barry (1981) with growing lambs, abomasal casein infusion depressed herbage voluntary MEI by an amount similar to the ME infused as casein. In contrast, glucose infusion depressed herbage MEI by an amount much greater than the ME infused as glucose, and depressed calculated amino acid absorption from 0.18 to 0.14 of ME. For a given diet, it has long been recognized that there is an optimum value for amino acid absorption as a proportion of ME to achieve maximum voluntary intake (Weston, 1979). It would appear that glucose infusion depressed voluntary intake by lowering this value and this is reinforced by the increase in intake when glucose and casein were infused together. In a review of intake regulation in ruminants, Waldo (1985) concluded that the rate of rumen degradation and outflow of cell-wall OM was the principal factor restricting intake of 
roughage diets (as represented here by fresh forages), whereas intake of energy-dense feeds (as represented here by infusates) was under physiological control of the animal and proportional to its drive to produce. As the three infusion treatments all depressed herbage MEI in Expt 2, it seems that total MEI of the infused animals must have been under physiological control and regulated by their physiological state.

Oddy \& Annison (1979) reviewed the literature on changes in feed intake during late pregnancy and reported conflicting results, with some authors reporting a progressive decline and others a gradual increase. Our interpretation of Fig. 1 is that when amino acid absorption. lies within the range to produce maximum voluntary intake (i.e. glucose + casein infusion), MEI is either stable or falls with advancing pregnancy probably due to reduced rumen volume as a result of the expanding uterus. However, in the remaining three groups where amino acid absorption was not in the desired range and MEI therefore below maximum, increases in MEI towards the maximum were possible and did occur in late pregnancy. In agreement with all authors reported by Oddy \& Annison (1979), MEI in all groups declined during the last 3 days preceding parturition.

\section{Glucose production}

GIL as measured in the present experiments is the sum of gluconeogenesis from non-glucose precursors (including amino acids) and exogenous glucose infusion. Judson \& Leng (1973) reported endogenous GIL to be depressed by $0 \cdot 19$ units/unit exogenous glucose infused in dry sheep, a value similar to that found in the present study with pregnant ewes $(0 \cdot 2)$. Thus, the suppression of endogenous glucose production by exogenous glucose infusion was small in these ewes, with overall GIL being increased by an amount equivalent to 0.8 of the glucose infused. Krebs (1964) calculated a maximum of $57 \mathrm{~g}$ glucose produced if all the gluconeogenic non-essential amino acids in casein were converted to glucose. The mean value of $350 \mathrm{~g}$ additional glucose produced $/ \mathrm{kg}$ casein infused in Expt 2 represents $60 \%$ of the theoretical maximum, as also found by Barry et al. (1982) with growing lambs. It is well established that GIL is positively and linearly related to MEI (Schmidt \& Keith 1983), as shown by eqns (3) and (6) in the present study. However, in Expt 1 it seemed that the ewes given kale adapted to the low intake by passing a greater proportion of ME through the glucose pool.

\section{ME utilization}

The ME balance (MEB) has been calculated for each group by subtracting from MEI the cumulative total of a maintenance requirement and the ME requirement for fetal growth. The maintenance requirement used was $0.473 \mathrm{MJ} \mathrm{ME} / \mathrm{kg} \mathrm{W}^{0.75}$ per d, derived by Rattray \& Joyce (1976) in comparative slaughter experiments in NZ with sheep given fresh ryegrass and white clover. Energy deposition in the gravid uterus during the last 4 weeks of pregnancy was taken from Agricultural Research Council (1980), adjusted for the lamb birth weights recorded here, and divided by an efficiency of utilization of ME for conceptus growth of 0.13 (Rattray et al. 1974) to give the amount of ME required for fetal growth. Negative MEB values were recorded for all groups (Fig. 2). No attempt has been made to convert MEB to energy balance, as the required efficiency factor is unknown under NZ conditions and would probably be influenced by glucose and casein infusion. Nevertheless, the negative MEB values suggest negative energy balance in all groups, as indeed found by Robinson et al. (1978) for ewes carrying quadruplet lambs during late pregnancy and fed at similar MEI to those used here; rates of fat mobilization from the carcass during the last 4 weeks were $130 \mathrm{~g} / \mathrm{d}$.

Decreases in MEI from 0.8 to $0.6 \mathrm{MJ} / \mathrm{kg} \mathrm{W}^{0.75}$ per d produced a reduction in MEB but no change in birth weight, which appeared to be constant at 0.21 of live weight. Further decrease in MEI to $0.5 \mathrm{MJ} / \mathrm{kg} \mathrm{W}^{0.75}$ per d produced little further changes in MEB, but 


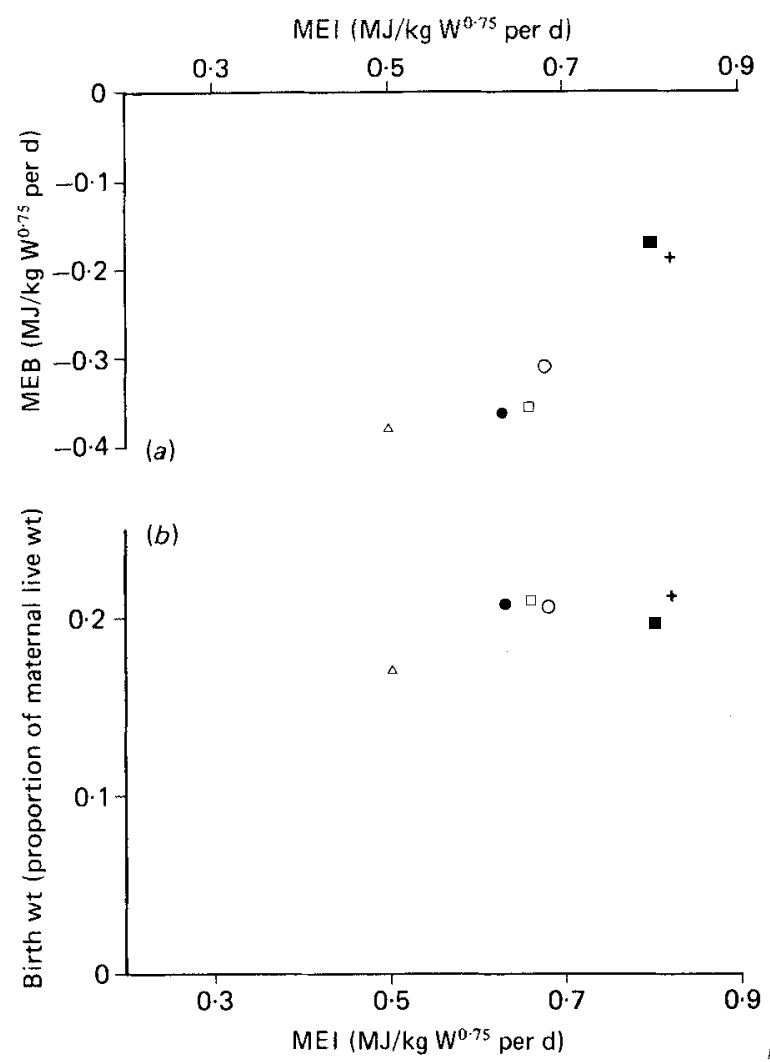

Fig. 2. (a) Metabolizable energy balance (MEB) and (b) total lamb birth weight as a proportion of maternal live weight (W) $v$. voluntary metabolizable energy intake (MEI) (herbage +infusate). Expt 1: $(\triangle)$, kale (Brassica oleracea) diet ; + , perennial ryegrass (Lolium perenne) diet. Expt $2:(O)$, control ewes; $(\odot)$, glucose infused; $(\square)$, casein infused; ( $\square$ ), glucose + casein infused. MEB is defined as MEI minus the cumulative total of metabolizable energy required for maintenance + growth of the gravid uterus.

depressed birth weight. Utilization of the two components of ME required for fetal growth, glucose and amino acids, will now be examined.

\section{Glucose utilization}

Wilson et al. (1983) claimed that ewes given a constant diet in late pregnancy could increase gluconeogenesis in accordance with increased fetal demands, and that the relation between total lamb birth weight (LBW; $\mathrm{kg}$ ) and GIL $(\mathrm{mg} / \mathrm{min}$ ) could be described by the equation:

$$
\mathrm{LBW}=-1.7(\mathrm{SE} 1.20)+0.082(\mathrm{SE} 0.0112) \mathrm{GIL}(n 24, r 0.84, P<0.001) \text {. }
$$

A similar relation was derived for ewes used in the present study, excluding those infused with glucose, which was described by the equation:

$$
\mathrm{LBW}=2.9(\mathrm{SE} 1.32)+0.055(\mathrm{SE} 0.0120) \mathrm{GIL}(n 14, r 0.84, P<0.01) .
$$

Regression eqns (7) and (8) apply over the same range and do not differ in slope. However, a more realistic approach (Fig. 3), using all groups of the present study, is to relate LBW $(\mathrm{kg})$ to GIL $(\mathrm{mg} / \mathrm{min})$ by the equation:

$$
\mathrm{LBW}=12.3(\text { SE 0.92) }-384.1(\mathrm{SE} 104.17) \times(1 / \mathrm{GIL})(n 19, r 0.69, P<0.01) .
$$




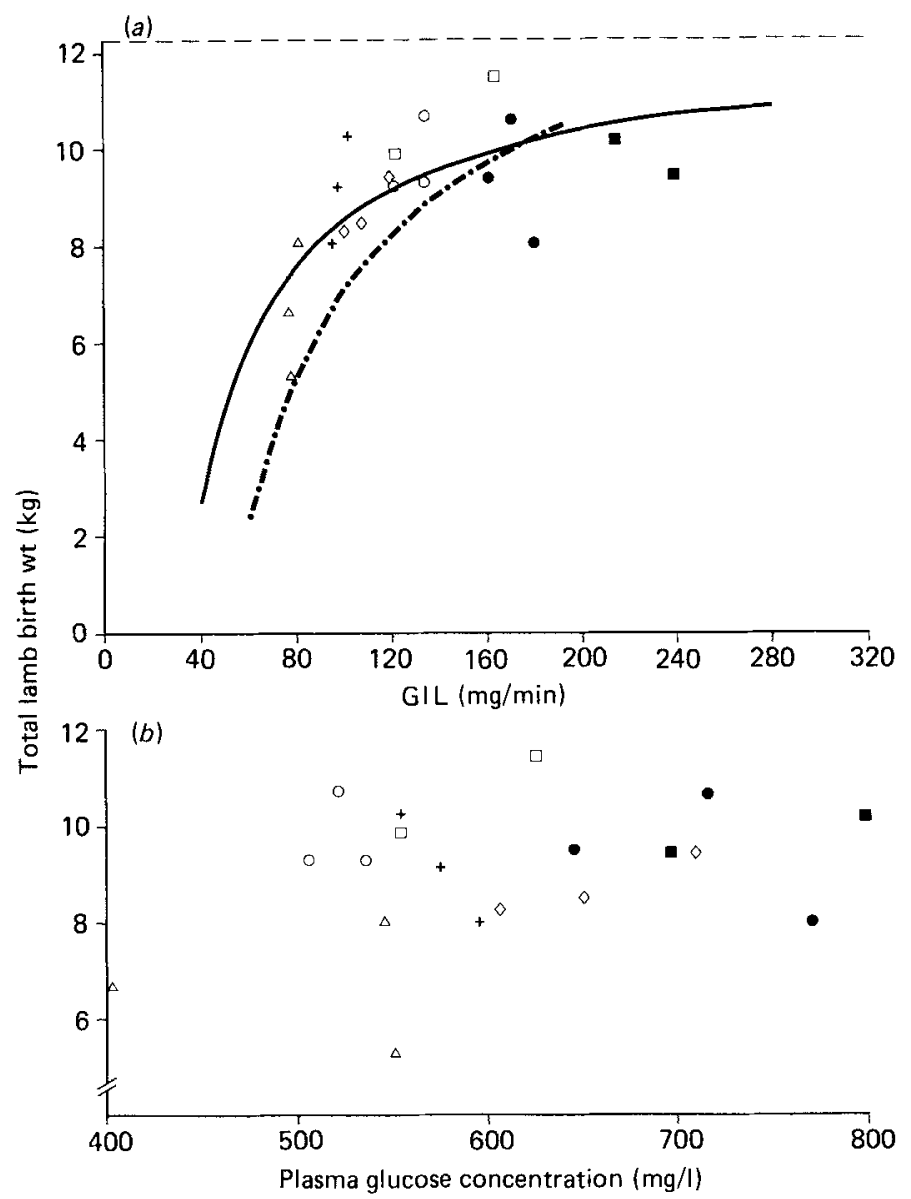

Fig. 3. Total lamb birth weight $(\mathrm{kg}) v$. (a) rate of glucose irreversible loss (GIL) from plasma and (b) plasma glucose concentration. Expt 1: $(\triangle)$, kale (Brassica oleracea) diet $;(+)$, perennial ryegrass (Lolium perenne) diet; $(\diamond)$, barley $(0.25)$ - perennial ryegrass $(0.75)$ diet. Expt $2:(0)$, control ewes; $(\bullet)$, glucose infused; $(\square)$, casein infused; $(\square)$, glucose + casein infused. (-), Fitted curve for all groups in the present study (eqn (9)). (--.---), Fitted curve for values from Wilson et al. (1983) (eqn (10)). (----), Asymptote or predicted maximum total lamb birth weight for the present study.

The theoretical maximum birth weight $(4 \cdot 1 \mathrm{~kg} / \mathrm{lamb})$ was considerably greater than the mean value obtained in Expt $2(3.3 \mathrm{~kg})$. Shearing of ewes some 6 weeks before parturition has consistently increased the birth weight of twin lambs (Austin \& Young, 1977) and triplet lambs born to ewes of the same genotype used here (G. H. Davis, unpublished results) by a total of $0.9-1.3 \mathrm{~kg}$. Shearing also produces a large reduction ( 1.2 litres) in rumen fluid volume (Weston, 1983), thus allowing the developing uterus to expand. It may well be that low maternal body-weight of the genotype used here set an upper limit to fetal size, and thereby prevented full expression of an increase in GIL. Reductions in GIL below about $120 \mathrm{mg} / \mathrm{min}(173 \mathrm{~g} / \mathrm{d})$ were, however, associated with large reductions in birth weight.

Analysis of the data of Wilson et al. (1983) by this method yields the equation:

$$
\text { LBW }=14.3(\text { SE 1.35) }-723.9(\text { SE 127.48) } \times(1 / \text { GIL })(n 24, r 0.77, P<0.001) \text {. }
$$

The question as to whether glucose supply restricts fetal growth can only be resolved by calculating an independently determined conceptus glucose requirement, and comparing 
this with maternal GIL determined in the present study. Fetal glucose turnover measurements based on isotope dilution procedures have been criticized, due to flow back of the infusate into the maternal circulation (Hay et al. 1981). For this reason a conceptus (placenta + fetus) glucose requirement of $100 \mathrm{mg} / \mathrm{min}(144 \mathrm{~g} / \mathrm{d})$ in late pregnancy has been calculated for the present study, based on arteriovenous blood flow measurements using the Fick principle (Meschia et al. 1980). Based on this value, glucose production could have been restricting fetal growth in kale-fed sheep $(123 \mathrm{~g} / \mathrm{d})$ but would be non-limiting in the groups infused with glucose, casein and glucose + casein in Expt 2 (205-325 g/d). In the other three groups comprising sheep given perennial ryegrass without abomasal supplementation, glucose supply was borderline (142-184 g/d), and the lack of a response to glucose infusion indicates either that fetal glucose requirements could just be met provided maternal glucose requirements were reduced to a minimum, or else there was some degree of fetal gluconeogenesis (Hay et al. 1984). Lamb birth weight (Fig. 3(b)) was not related to maternal glucose concentration, except for the low values recorded for ewes given kale.

\section{Amino acid utilization}

Maternal $\mathrm{N}$ balance can be calculated from net amino acid $\mathrm{N}$ absorption and net protein requirements (NPR) using the procedure and assumptions shown in the Appendix. NPR was calculated as the cumulative requirement of protein for growth of the gravid uterus in late pregnancy, maternal endogenous $\mathrm{N}$ excretion, maternal wool growth and fetal oxidation of amino acids for energy. A biological value of 0.67 , derived with rumen micro-organisms (Storm et al. 1983), was assumed to apply.

These calculations (Appendix) essentially show that, in the absence of casein infusion, the ewes in Expt 2 were in negative $N$ balance ( $5-8 \mathrm{~g} / \mathrm{d}$ ), as observed in practice by Robinson et al. (1978). Furthermore, whilst infusions of casein restored positive $\mathrm{N}$ balance (3-5 g/d), they did not produce increased fetal growth. In ewes given fresh ryegrass, these conclusions are in accordance with amino acid requirements of the triplet-bearing ewe in late pregnancy exceeding net absorption from digestion of the diet, with maternal tissues subsequently going into negative $\mathbf{N}$ balance to ensure fetal growth. With the kale diet, the large reduction in calculated net amino acid uptake, derived from Barry et al. (1984), was associated with both depressed birth weight and calculated negative maternal $\mathrm{N}$ balance. These conclusions are also open to the criticism that predicting amino acid absorption of pregnant sheep from values derived with non-pregnant animals may result in an underestimation of up to $20 \%$ (Faichney, 1984); however, even if these values were increased by $30 \%$ in the Appendix, it would not invalidate the conclusions drawn.

In conclusion, it seems that in the present study, low maternal body size may have limited uterine expansion and, therefore, set an upper limit on birth weight. Products of digestion and metabolism of the unsupplemented fresh forages were calculated to be deficient in amino acids and borderline to deficient in glucose to meet the requirements for conceptus growth, but this was ensured by maternal tissues going into negative energy and protein balance. Hence, only a very severe reduction in amino acid absorption and glucose production from dietary sources markedly depressed fetal growth.

The authors would like to thank Mr S. J. Duncan, Mr B. A. Veenvliet, Mr A. W. Williams and Miss G. Caughey for skilled technical assistance, and Dr C. G. Mackintosh for advice and assistance with surgical procedures. 


\section{REFEREN CES}

Agricultural Research Council (1980). The Nutrient Requirement of Ruminant Livestock, pp. 7-8. Slough: Commonwealth Agricultural Bureaux.

Agricultural Research Council (1983). The Nutrient Requirement of Ruminant Livestock (Interim report). Slough : Commonwealth Agricultural Bureaux.

Austin, A. R. \& Young, N. E. (1977). Veterinary Record 100, 527-529.

Barry, T. N. (1980). New Zealand Journal of Agricultural Research 23, 427-431.

Barry, T. N. (1981). British Journal of Nutrition 46, 521-532.

Barry, T. N., Manley, T. R. \& Duncan, S. J. (1984). Journal of Agricultural Science, Cambridge 102, $479-486$.

Barry, T. N., Manley, T. R., Redekopp, C. \& Allsop, T. M. (1985). British Journal of Nutrition 54, $165-173$.

Barry, T. N., Manley, T. R., Redekopp, C., Davis, S. R., Fairclough, R. J. \& Lapwood, K. R. (1982). British Journal of Nutrition 47, 319-329.

Blaxter, K. L. (1962). Energy Metabolism of Ruminants. London: Hutchinsons.

Blaxter, K. L. (1977). In Nutrition and the Climate Environment, pp. 1-16 [W. Haresign, H. Swan and D. Lewis, editors]. London: Butterworths.

Dalton, D. C., Knight, T. W. \& Johnson, D. L. (1980). New Zealand Journal of Agricultural Research 23, $167-173$.

Davis, G. H. \& Hinch, G. N. (1984). In The Genetics of Reproduction in Sheep, pp. 139-149 [R. B. Land and D. W. Robinson, editors]. London: Butterworths.

Davis, G. H., Montgomery, G. W., Allison, A. J., Kelly, R. W. \& Bray, A. R. (1982). New Zealand Journal of Agricultural Research 25, 525-529.

Faichney, G. J. (1981). Proceedings of the Nutrition Society of Australia 6, 48-53.

Faichney, G. J. (1984). In Feed Information and Animal Production, pp. 191-192 [G. W. Robarts, editor]. Slough: Commonwealth Agricultural Bureaux.

Hay, W. W., Sparks, J. W., Quissell, B. J., Battaglia, F. C. \& Meschia, G. (1981). American Journal of Physiology 240, E662-E668.

Hay, W. W., Sparks, J. W., Wilkening, R. B., Battaglia, F. C. \& Meschia, G. (1984). American Journal of Physiology 246, E237-E242.

Hopkins, P. S. (1975). In Digestion and Metabolism in the Ruminant, pp. 1-14. [I. W. McDonald and A. C. I. Warner, editors]. Armidale, Australia: University of New England Publishing Unit.

Judson, G. J. \& Leng, R. A. (1973). British Journal of Nutrition 29, 159-174.

Krebs, H. A. (1964). In Mammalian Protein Metabolism, pp. 125-176 [H. N. Munro and J. B. Allison, editors]. New York: Academic Press.

MacRae, J. C. \& Ulyatt, M. J. (1974). Journal of Argricultural Science, Cambridge 82, 309-319.

Meschia, G., Battaglia, F. C., Hay, W. W. \& Sparks, J. W. (1980). Federation Proceedings 39, $245-248$.

Newton-Turner, H. (1982). The Booroola Merino, pp. 1-7 [L. R. Piper, B. M. Bindon and R. D. Nethery, editors]. Sydney, Australia: CSIRO Division of Animal Production.

Oddy, V. H. \& Annison, E. F. (1979). In Physiological and Environmental Limitations to Wool Growth, pp. 295-309 [J. L. Black and R. J. Reis, editors]. Armidale, Australia: University of New England Publishing Unit.

Piper, L. R. \& Bindon, B. M. (1982). In The Booroola Merino, pp. 9-19 [L. R. Piper, B. M. Bindon and R. D. Nethery, editors]. Sydney, Australia: CSIRO Division of Animal Production.

Rattray, P. V., Garret, W. N., Wast, N. E. \& Hinman, N. (1974). Journal of Animal Science 38, 383-393.

Rattray, P. V. \& Joyce, J. P. (1976). New Zealand Journal of Agricultural Research 17, 401-406.

Robinson, J. J., McDonald, I., McHattie, I. \& Pennie, K. (1978). Journal of Agricultural Science, Cambridge 91, 291-304.

Schmidt, S. P. \& Keith, R. K. (1983). Journal of Nutrition 113, 2155-2163.

Storm, E., Ørskov, E. R. \& Smart, R. (1983). British Journal of Nutrition 50, 471-478.

Ulyatt, M. J., Fennessy, P. F., Rattray, R. V. \& Jagusch, K. T. (1980). In Supplementary Feeding, pp. 157-184 [K. R. Drew and P. F. Fennessy, editors]. Invermay Research Centre, Mosgiel, New Zealand: New Zealand Society of Animal Production.

Waldo, D. R. (1985). In Forage Legumes for Energy-Efficient Animal Production, [R. F. Barnes, D. J. Minson and R. W. Brougham, editors]. Sydney, Australia: USDA/CSIRO/DSIR (In the press).

Weston, R. H. (1979). In Physiological and Environmental Limitations to Wool Growth pp. 163-177 [J. L. Black and P. J. Reis, editors]. Armidale, Australia: University of New England Publishing Unit.

Weston, R. H. (1983). Proceedings of the Nutrition Society of Australia 8, 181-184.

Wilson, S., MacRae, J. C. \& Buttery, P. J. (1983). British Journal of Nutrition 50, 303-316. 
Appendix. Method and assumptions in calculating maternal tissue nitrogen balance

\begin{tabular}{|c|c|c|c|c|c|c|}
\hline & \multicolumn{2}{|c|}{ Expt 1} & & & & \\
\hline & \multirow{2}{*}{$\begin{array}{c}\text { Kale } \\
\text { (Brassica } \\
\text { oleracea) }\end{array}$} & \multirow{2}{*}{$\begin{array}{c}\text { Perennial } \\
\text { ryegrass } \\
\text { (Lolium } \\
\text { perenne) }\end{array}$} & \multicolumn{4}{|c|}{ Expt 2} \\
\hline & & & Control & Glucose & Casein & $\begin{array}{l}\text { Glucose }+ \\
\text { casein }\end{array}$ \\
\hline $\begin{array}{l}\text { Amino acid uptake } \times \text { BV } \\
(\mathrm{g} / \mathrm{d})\end{array}$ & 31.8 & $76 \cdot 3$ & 62.0 & $44 \cdot 2$ & $129 \cdot 0$ & 133.7 \\
\hline \multicolumn{7}{|l|}{$\begin{array}{l}\text { Net protein requirement } \\
(\mathrm{NPR} ; \mathrm{g} / \mathrm{d})\end{array}$} \\
\hline Wool growth* & 0 & $2 \cdot 2$ & $2 \cdot 24$ & $2 \cdot 28$ & $5 \cdot 30$ & 4.83 \\
\hline \multicolumn{7}{|l|}{ Endogenous: } \\
\hline Maternal $\dagger$ & 34.9 & $35 \cdot 6$ & $40 \cdot 0$ & $38 \cdot 2$ & $41 \cdot 7$ & $42 \cdot 1$ \\
\hline Fetus $\ddagger$ & $9 \cdot 15$ & $12 \cdot 36$ & $13 \cdot 4$ & $12 \cdot 8$ & $14 \cdot 7$ & $13 \cdot 5$ \\
\hline Gravid uterus deposition $\S$ & 27.9 & $37 \cdot 7$ & $41 \cdot 0$ & $39 \cdot 2$ & $44 \cdot 8$ & $41 \cdot 2$ \\
\hline Total & 71.95 & $87 \cdot 86$ & $96 \cdot 64$ & $92 \cdot 48$ & $106 \cdot 5$ & $101 \cdot 63$ \\
\hline $\begin{array}{l}\text { Maternal tissue } N \text { retention } \\
(\mathrm{g} / \mathrm{d}) \|\end{array}$ & $-6 \cdot 43$ & -1.86 & $-5 \cdot 54$ & $-7 \cdot 73$ & +3.61 & $+5 \cdot 13$ \\
\hline
\end{tabular}

BV, biological value; $\mathrm{W}$, live weight.

* Converted from $\mathrm{mg} / 10^{4} \mathrm{~mm}^{2}$ per $\mathrm{d}$ using surface area $\left(\mathrm{m}^{2}\right)=0.09 \mathrm{~W}^{2 / 3}$ (Meeh formula; Blaxter, 1977).

$\dagger 350 \mathrm{mg} \mathrm{N} / \mathrm{kg} \mathrm{W}^{0} \cdot \mathbf{7 5}$ per $\mathrm{d}$ for urine + faeces (Agricultural Research Council, 1983).

$\ddagger 22 \mathrm{mg}$ urea-N synthesized/kg fetus per h (Faichney, 1981) and fetal weight at $120 \mathrm{~d}$ of 0.416 birth weight (Agricultural Research Council, 1980).

$\S$ Between 119 and $147 \mathrm{~d}$ from conception, adjusted for birth weights recorded in present study (Agricultural Research Council, 1980; Table 1.5).

$\|[$ (Amino acid $\mathrm{N}$ uptake from small intestine $\times \mathrm{BV})-\mathrm{NPR}] 6.25$. 